\title{
GLL
}

Geomatics, Landmanagement and Landscape No. $4 \cdot 2020,7-15$

\section{THE USE OF WEB APPLICATION IN MONITORING THE EFFECTS OF INTRODUCING FLOWER MEADOWS IN KRAKÓW'S CITY PARKS}

\author{
Dawid Bedla, Wiktor Halecki
}

\section{Summary}

Flower meadows provide opportunities for parks in city centres. Urban green areas combine elements of both natural and human origin, such as planning projects of management entities of green areas. Usually, these parks are compact and easy to separate, with objects intended for active and passive recreation, fully utilising the surroundings. On the basis of available planning documents and maps, the number, size and quality of green areas, including flower meadows in city parks, were determined. By examining the parks' functional and spatial structure, it is possible to identify the areas in vicinity of which they are located, as well as their purpose and nature. A web application could raise awareness of the role and importance of flower meadows in city parks as an element of public space. For this reason it is currently very important to preserve green areas by surveying the plant structure and dominant phytocoenoses, creating natural maps that present and collect data on the richness of green areas. When analysing the distribution of selected types of city parks, it is possible to observe the dependence of their location to the central parts of cities. The web application presents the distribution of green areas in the urban planning. The application will allow collecting data, which can enable creating a green infrastructure of the Kraków city centre and suburbs, and in the future to show eco-urban aspects in a cartographic form. In the next phase, the application will be extended to a description of the species of meadow plants occurring in city parks. It will not only add didactic elements to the urbanscape, but will also allow for conducting natural field activities, linking garden premises with the surroundings and using local plants.

\section{Keywords}

urban ecology $\bullet$ internet cartography $\bullet$ city landscape management $\bullet$ green areas planning

\section{Introduction}

Modern cities face increasing number of challenges, such as: air pollution, urban heat island, excess or scarcity of water, loss of natural habitats, as well as lack of social integration [Zobec et al. 2020]. Applying nature-based solutions is an effective way of coping with many of these issues simultaneously [Dushkova and Haase 2020]. Despite 
its significant potential, blue and green infrastructure is still under-researched and, therefore, little used in countering the effects of climate change and as means of urban adaptation [Valente et al. 2020]. Among barriers to the promotion of nature-based solutions are the lack of practical experience and technical knowledge in the field of planning and implementation, as well as a shortage of dedicated instruments for wide implementation in sectoral policies [Bedla and Król 2015, Velasco-Jiménez et al. 2020]. On the other hand, establishing green areas in cities is becoming more and more economically profitable. In order to convince the city community, which is concerned with aesthetic features of plants, an urban area must be as natural as possible [Sun et al. 2020].

Natural features, such as topography, hydrological, soil, climatic and botanical conditions, are the most important factors to be taken into account for proper development of green areas [Salizzoni et al. 2020]. Visual impressions and personal encounters have an impact on how synanthropic vegetation is experienced and accepted by citizens, whereas evaluating ecological types of vegetation is interesting to scientists [Tian et al. 2020]. In addition, green areas with attractive interiors allow the realization of some elements of landscape architecture and give a distinct and individual character to the city [Ronchi et al. 2020]. For this example, flower meadows are increasingly being promoted instead of traditional lawns, squares and flowerbeds. The use of ecofriendly design is also profitable for city governments, as improving the aesthetics of a city attracts investors [Sabyrbekov et al. 2020].

Plants obtain water from the soil together with mineral substances, transport it to the shoot, and then release water in the process of evapotranspiration. This process intensifies with an increase of temperature and a decrease of humidity, it also depends on soil moisture, light, wind and leaf structure [Suchocka 2011]. Thanks to a dense root system of vegetation, the soil is naturally relaxed and aerated, which significantly reduces the transmission of tremors and vibrations [Pearsall and Eller 2020]. Therefore, it is most important in urban areas, where proper planting of clusters of high-building greenery can effectively counteract the effects of floods, among others [Li et al. 2020].

In urban areas, the care of green areas and meadow runes takes various forms [Skutnik 2016]. In Kraków, conditioning of green areas in a form of flower meadows is gaining popularity [Halecki 2018]. The research employed interactive techniques for graphic presentation of designed green areas. The main idea was to show the economic legitimacy of incorporating flower meadows architecture in Kraków's city parks.

\section{Materials and methods}

The presentation of a green map of the city of Kraków (Fig. 1) was elaborated with the jQuery script - 'jZoom' (Pushpendra Singh Chouhan, MIT License). jZoom is a relatively simple jQuery component that provides a 'magnifying glass' effect in raster visualizations [jZoom 2020]. jQuery is a lightweight JavaScript programming library [Andreasen and Møller 2014, Król and Szomorova 2015]. 


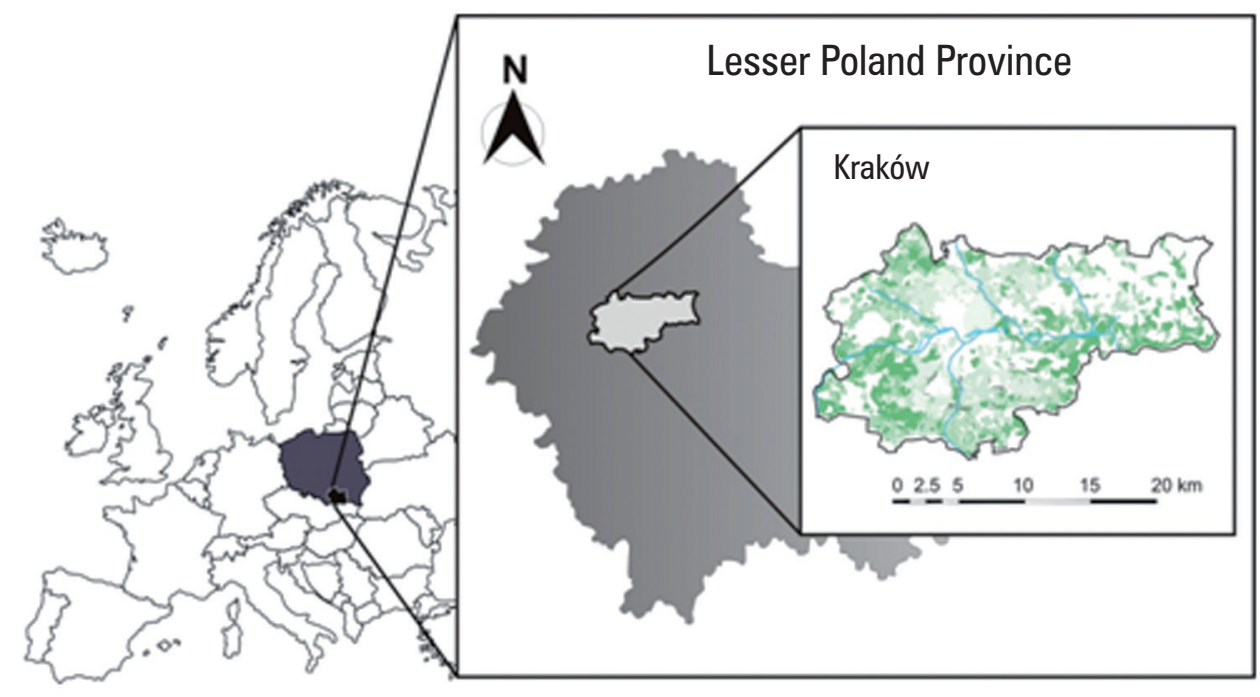

Fig. 1. Green map of the city of Kraków, jQuery script - ‘jZoom’ (Pushpendra Singh Chouhan, MIT License)

Today, most JavaScript web applications use libraries to secure the functionality of web applications. Research has shown that $58 \%$ of the top 10 million websites use jQuery, and its market share among JavaScript libraries amounts to 93.4\% [W3Techs 2014]. Urban green areas in Kraków are also presented in an application written in jfMagnify (Fig. 2).

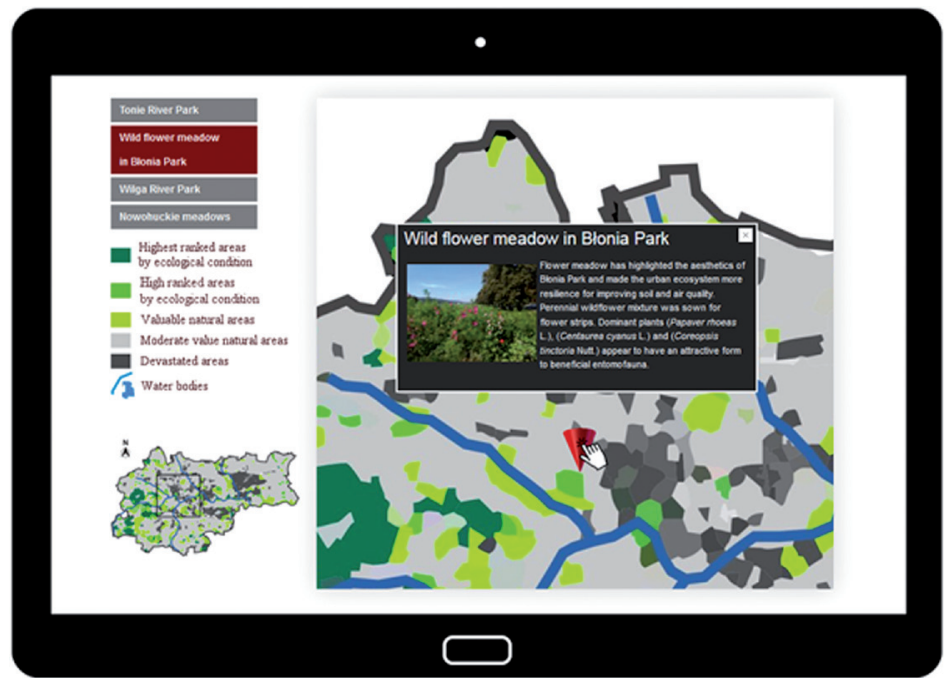

Fig. 2. Urban green areas in Kraków - jfMagnify 
jfMagnify is a jQuery plug-in that produces a 'magnifying glass' effect. The 'magnifying glass' window zooms in on hypertext elements, not just graphic files [Fahnestock 2020]. This is a modular solution. The presentation consists of a compact set of scripts, and the layout is determined by cascading CSS style sheets and JavaScript attribute settings. The whole can be personalized and implemented in a structure of any hypertext document. The created application presents an enlarged view of the map in an additional window.

Moreover, the measurements of the area of flower meadows in Kraków city parks were carried out with the use of generally available geoinformatics tools available at geoportal.gov.pl. The costs of creating and maintaining flower meadows in selected Kraków city parks were estimated based on source data.

\section{Results and discussion}

\subsection{Concept of spatial management of green areas}

City parks are an element of the city's functional-spatial structure. They can be found both in cities and in rural areas, and are intended for a diverse public [Czortek and Pielech 2020]. Introduced there parks and flower meadows provide increasingly often a valuable research area for naturalists and botanists. Moreover, they also belong to public space, as they usually provide vegetation openly accessible for everyone. City parks do not have to, and sometimes cannot fulfil all ecological functions, or they can only perform them to a certain degree [Luo et al. 2020]. The shape of green areas is closely related to the development of the city's functional-spatial structure [Fei et al. 2020]. Such analyses may become a basic material for indicating the location of such spaces in residential areas, especially due to the growing significance of city parks [Beckett et al. 2020]. It is worth making the effort and starting cooperation by defining the ecophysiographic principles of shaping the spatial structure of cities in development plans [Langemeyer et al. 2020]. The proper functional-spatial structure next to a green unit (preferred functions in the vicinity of parks: residential, service, green areas), helps to ensure spatial order and has a positive influence on the quality of leisure in a green area - especially when it is small. It also provides a sense of security and better availability of greenery [Mihankhah et al. 2020, Zheng et al. 2020]. Ecological landscape management is achieved, among other, due to the fact that vegetation impacts the formation of a city landscape and the shaping of soil conditions [Wan et al. 2020].

Parks should have a diversified infrastructure, including small architecture. So far, no studies have been carried out on the distribution of different types of parks and their functions for individual elements of city structure [Szczepańsk and Pietrzyk 2020], which is an important part in the process of park management and shaping [Baumeister et al. 2020]. On this basis sites for new, attractive areas with vegetation, such as flower meadows, are determined (Fig. 3). The date of their creation falls on the beginning of the growing season (usually in the second decade of April). The indicated sites are public urban areas, including parks and lawns, road lanes, squares and flowerbeds. 


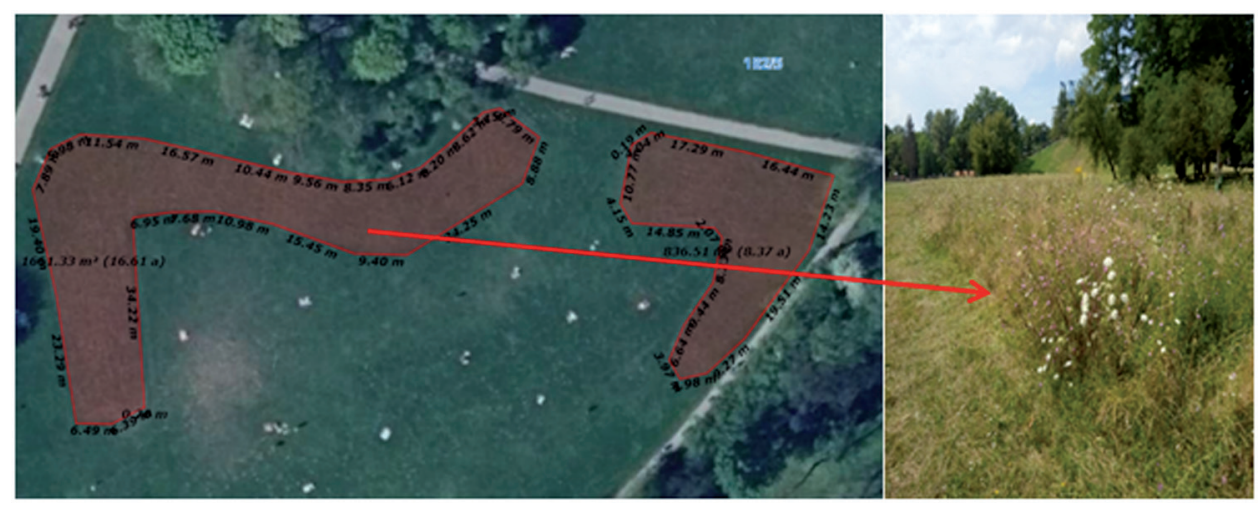

Fig. 3. Sites for new, attractive areas with vegetation

\subsection{Analysis of the costs of creating and maintaining flower meadows}

Ensuring the sustainability of urban green areas is an expensive operation. However, compared to traditional lawns, flower meadows in city parks require less financial and material expenditure. The estimated costs of creating and maintaining an individual flower meadow in a city park are presented in Tables 1 and 2.

Table 1. Estimated costs of creating flower meadows in Kraków city parks (average unit costs based on the Citizen's Budget of the City of Kraków in 2016-2020)

\begin{tabular}{|l|c|c|c|c|c|}
\hline \multicolumn{1}{|c|}{ Works and treatments } & Unit & $\begin{array}{c}\text { Park } \\
\text { Jordana }\end{array}$ & $\begin{array}{c}\text { Błonia } \\
\text { Krakowskie }\end{array}$ & $\begin{array}{c}\text { Park Lotników } \\
\text { Polskich }\end{array}$ & $\begin{array}{c}\text { Park } \\
\text { Tysiąclecia }\end{array}$ \\
\hline Turf unplanting with export & $13 \mathrm{PLN} / \mathrm{m}^{2}$ & 33150 & 1560 & 3250 & 3380 \\
\hline Deep ploughing & $10 \mathrm{PLN} / \mathrm{m}^{2}$ & 25500 & 1200 & 2500 & 2600 \\
\hline $\begin{array}{l}\text { Application of fertile soil } \\
\text { uniformly - a layer with } \\
\text { a thickness of } 5 \mathrm{~cm}\end{array}$ & $100 \mathrm{PLN} / \mathrm{m}^{3}$ & 16000 & 7500 & 1560 & 1560 \\
\hline Levelling fertile land & $50 \mathrm{PLN} / \mathrm{m}^{3}$ & 3000 & 400 & 750 & 800 \\
\hline $\begin{array}{l}\text { Mixture of grass and perennial } \\
\text { seeds }\end{array}$ & $5 \mathrm{PLN} / \mathrm{m}^{2}$ & 12750 & 600 & 1250 & 1300 \\
\hline Seed sowing & $4 \mathrm{PLN} / \mathrm{m}^{2}$ & 10200 & 480 & 1000 & 1040 \\
\hline Rolling & $1 \mathrm{PLN} / \mathrm{m}^{2}$ & 2550 & 120 & 250 & 260 \\
\hline Initial watering & $3 \mathrm{PLN} / \mathrm{m}^{2}$ & 7650 & 360 & 750 & 780 \\
\hline Sum & $\mathrm{PLN}$ & 110800 & 12220 & 11310 & 11720 \\
\hline The area of a flower meadow & $\mathrm{m}{ }^{2}$ & 2550 & 120 & 250 & 260 \\
\hline
\end{tabular}


Flower meadows in parks fit in with the idea of garden city. Despite the fact that flower meadows involve relatively high initial costs, these plant communities are an economically viable alternative to urban lawns. The highest cost is land fertilization (Table 1). Limiting mowing to two or three times per season saves a lot of money on the maintenance of flower meadows (Table 2). Flower meadows should be gradually renewed, but the costs associated with maintaining its durability in the following years are limited (including removing turf, deep ploughing or delivering fertile soil). The basic procedure to be conducted in the following year is sowing seeds.

Table 2. Annual estimated expenditure on the care of flower meadows in Kraków city parks (data according to the Katalog Nakładów Rzeczowych 2016), values in PLN

\begin{tabular}{|l|c|c|c|c|}
\hline \multicolumn{1}{|c|}{ Expenditure } & $\begin{array}{c}\text { Park } \\
\text { Jordana }\end{array}$ & $\begin{array}{c}\text { Błonia } \\
\text { Krakowskie }\end{array}$ & $\begin{array}{c}\text { Park Lotników } \\
\text { Polskich }\end{array}$ & $\begin{array}{c}\text { Park } \\
\text { Tysiąclecia }\end{array}$ \\
\hline Mowing in the growing season & 558 & 26 & 54 & 56 \\
\hline Weeding & 0 & 0 & 0 & 0 \\
\hline Mineral and organic fertilisation & 0 & 0 & 0 & 0 \\
\hline Raking with leaving biomass & 1012 & 47 & 99 & 103 \\
\hline Watering & 0 & 0 & 0 & 0 \\
\hline Sum (PLN) & 1570 & 73 & 153 & 159 \\
\hline
\end{tabular}

* Assuming a single swath in the growing season and leaving biomass

Considering a growing significance of these sites, investigating availability of city parks with all academically known standards is fully legitimate and needed, too [Battisti et al. 2020]. It should be noted that not every park is suitable (e.g. environmentally and technically) for watercourses or larger water reservoirs, but it is always has the conditions for establishing flower meadows. Their absence or small area may result from many factors, among which previous intensive investments in construction objects, high density of trees, small park area or topography should be mentioned [Andrusaityte et al. 2020]. The fact that individual parks perform various functions is confirmed, among others, by distinguishing their multiple and changing over time types. The above is also related to green areas, which are usually small in the central parts of cities, and large further out from the centre [Arvanitidis and Papagiannitsis 2020]. In cities where there is a continuous natural system, though with parks located outside of it, above all, it is advisable to undertake measures that in the long term will allow the parks to be included in the existing continuous natural system [Zhao et al. 2020].

\section{Summary and conclusions}

Web application may be useful in monitoring the change in the total green areas in order to determine the factors in recreational satisfaction of the use of green areas and 
the degree of their fragmentation and management. The presentation of online data can be extended with the following functions in the natural system: emotional impact, social expectations of the park management, as well as satisfaction and reported problems, expectations and needs of citizens affecting the quality of life. Moreover, in most of parks additional recreational, educational and cultural events are organised. In the case of Kraków, the possibility of including parks located outside the city's central parts into the existing and requiring expansion system of public spaces should be considered. For this purpose, it is necessary to identify factors that determine the performance of a specific function. The first of these are the elements of landscaping. It can also be noted that on the outskirts of cities (including Kraków) there are mainly green facilities, the development of which only determines the recreational function. Meanwhile, interest in creating compositional arrangements in the form of extensive flower meadows in city parks is growing. Despite the relatively high cost of their installation, their subsequent use is relatively cheap. The key issue is a rationally conducted urban policy towards sustainable development and shaping of spatial structure. The species composition, and in particular sowing of native plant species, are also very beneficiary for honeybees, necessary for proper development of urban ecosystem.

Funded with a subsidy of the Ministry of Science and Higher Education for the University of Agriculture in Krakow for 2020.

\section{References}

Andreasen E., Møller A. 2014. Determinacy in static analysis for jQuery. Proceedings of the 2014 ACM International Conference on Object Oriented Programming Systems Languages \& Applications, 17-31. https://doi.org/10.1145/2660193.2660214

Andrusaityte S., Grazuleviciene R., Dedele A., Balseviciene B. 2020. The effect of residential greenness and city park visiting habits on preschool Children's mental and general health in Lithuania: A cross-sectional study. International Journal of Hygiene and Environmental Health, 223(1), 142-150.

Arvanitidis P.A., Papagiannitsis G. 2020. Urban open spaces as a commons: The credibility thesis and common property in a self-governed park of Athens, Greece. Cities, 97, 102480.

Battisti L., Pomatto E., Larcher F. 2020. Assessment and Mapping Green Areas Ecosystem Services and Socio-Demographic Characteristics in Turin Neighbourhoods (Italy). Forests, 11(1), 25.

Baumeister C.F., Gerstenberg T., Plieninger T., Schraml U. 2020. Exploring cultural ecosystem service hotspots: Linking multiple urban forest features with public participation mapping data. Urban Forestry \& Urban Greening, 48, 126561.

Beckett J. 2020. Public parks and urban development during the nineteenth and twentieth centuries in Nottingham. Midland History, 1-20.

Bedla D., Król K. 2015. An interactive map of mountain river hydromorphological diversity case study. Geomatics, Landmanagement and Landscape (GLL), 4, 17-27. DOI: 10.15576/ GLL/2015.4.17

Czortek P., Pielech R. 2020. Surrounding landscape influences functional diversity of plant species in urban parks. Urban Forestry \& Urban Greening, 47, 126525. 
Dushkova D., Haase D. 2020. Not Simply Green: Nature-Based Solutions as a Concept and Practical Approach for Sustainability Studies and Planning Agendas in Cities. Land, 9(1), 19.

Fahnestock J. 2020. jfMagnify plugin. GitHub. https://github.com/fonstok/jfMagnify

Fei W., Wu J., Shi Y., Chen Q. 2020. Construction of disaster prevention capability evaluation framework of urban park system: Methodology and its application in China. Journal of Environmental Engineering and Landscape Management, 28(1), 9-19.

Halecki W. 2018. Łąki kwietne w Krakowie sposobem na poprawę jakości życia w przestrzeni miejskiej. Wszechświat, 119(10-12), 262-263.

jZoom. 2020. Performant Image Magnifying Glass Effect With jQuery - jZoom. https://www. jqueryscript.net/zoom/Performant-Image-Magnifying-Glass-Effect-With-jQuery-jZoom. html

Katalog Nakładów Rzeczowych. 2016 (KNR 2-21, rozdz. IV: Wykonanie łąk parkowych siewem na terenie płaskim).

Król K. 2019. Zoomlens - graphic form of data presentation on a web map, comparison of chosen tool and usage examples. Engineering for Rural Development, 18, 1641-1648. DOI: https://doi.org/10.22616/ERDev2019.18.N002.

Król K., Szomorova L. 2015. The possibilities of using chosen jQuery JavaScript components in creating interactive maps. Geomatics, Landmanagement and Landscape (GLL), 2, 45-54. DOI: $10.15576 / \mathrm{gll} / 2015.2 .45$.

Langemeyer J., Wedgwood D., McPhearson T., Baró F., Madsen A.L., Barton D.N. 2020. Creating urban green infrastructure where it is needed. A spatial ecosystem service-based decision analysis of green roofs in Barcelona. Science of the Total Environment, 707, 135487.

Li L., Uyttenhove P., Vaneetvelde V. 2020. Planning green infrastructure to mitigate urban surface water flooding risk. A methodology to identify priority areas applied in the city of Ghent. Landscape and Urban Planning, 194, 103703.

Luo T., Yang F., Wu L., Gao X. 2020. Equity evaluation of urban park system: a case study of Xiamen, China. Journal of Environmental Engineering and Landscape Management, 28(3), $125-136$.

Mihankhah T., Saeedi M., Karbassi A. 2020. A comparative study of elemental pollution and health risk assessment in urban dust of different land-uses in Tehran's urban area. Chemosphere, 241, 124984.

Pearsall H., Eller J.K. 2020. Locating the green space paradox: A study of gentrification and public green space accessibility in Philadelphia, Pennsylvania. Landscape and Urban Planning, 195, 103708.

Ronchi S., Arcidiacono A., Pogliani L. 2020. Integrating green infrastructure into spatial planning regulations to improve the performance of urban ecosystems. Insights from an Italian case study. Sustainable Cities and Society, 53, 101907.

Sabyrbekov R., Dallimer M., Navrud S. 2020. Nature affinity and willingness to pay for urban green spaces in a developing country. Landscape and Urban Planning, 194, 103700.

Salizzoni E., Allocco M., Murgese D., Quaglio G. 2020. From Ecosystem Service Evaluation to Landscape Design: The Project of a Rural Peri-urban Park in Chieri (Italy). Values and Functions for Future Cities, 267-283, Springer, Cham.

Skutnik E. 2016. Łąka kwietna - pomysł godny każdego miasta. Zieleń Miejska, 3, 36-38.

Sun T., Yang L., Sun R., Chen L. 2020. Key factors shaping the interactions between environment and cities in megalopolis area of north China. Ecological Indicators, 109, 105771.

Tian Y., Wu H., Zhang G., Wang L., Zheng D., Li S. 2020. Perceptions of ecosystem services, disservices and willingness-to-pay for urban green space conservation. Journal of Environmental Management, 260, 110140. 
Urząd Miasta Krakowa. Budżet obywatelski 2016-2020.

Valente D., Pasimeni M.R., Petrosillo I. 2020. The role of green infrastructures in Italian cities by linking natural and social capital. Ecological Indicators, 108, 105694.

Velasco-Jiménez M.J., Alcázar P., Cariñanos P., Galán C. 2020. Allergenicity of the urban green areas in the city of Córdoba (Spain). Urban Forestry \& Urban Greening, 126600.

Wan J.Z., Li Q.F., Wei G.L., Yin G.J., Wei D.X., Song Z.M., Wang C.J. 2020. The effects of the human footprint and soil properties on the habitat suitability of large old trees in alpine urban and periurban areas. Urban Forestry \& Urban Greening, 47, 126520.

W3Techs. 2014. Usage of JavaScript libraries for websites. http://w3techs.com /technologies/ overview/javascript_library/all

Zepp H., Groß L., Inostroza L. 2020. And the winner is? Comparing urban green space provision and accessibility in eight European metropolitan areas using a spatially explicit approach. Urban Forestry \& Urban Greening, 126603.

Zhao Y., Liu Z., Wu J. 2020. Grassland ecosystem services: A systematic review of research advances and future directions. Landscape Ecology, 1-22.

Zheng S., Cui K., Sun S., Wu J., Qiu Q., Tian Y. 2020. Planning and design based on landsenses ecology: The case study of Chongming Island Landsenses Ecol-industrial Park. International Journal of Sustainable Development \& World Ecology, 1-8.

Zobec M., Betz O., Unterweger P.A. 2020. Perception of Urban Green Areas Associated with Sociodemographic Affiliation, Structural Elements, and Acceptance Stripes. Urban Science, 4(1), 9.

Dr inż. Dawid Bedla

Uniwersytet Rolniczy w Krakowie

Katedra Ekologii, Klimatologii i Ochrony Powietrza

al. Mickiewicza 24/28, 30-059 Kraków

e-mail: dawid.bedla@urk.edu.pl

ORCID: 0000-0003-0500-1443

Mgr inż. Wiktor Halecki

Uniwersytet Rolniczy w Krakowie

Katedra Melioracji i Kształtowania Środowiska

al. Mickiewicza 24/28, 30-059 Kraków

e-mail:w.halecki@urk.edu.pl

ORCID: 0000-0001-7802-2849 